\title{
Genç Girişimciliği ve Sosyal Girişimcilik: Üniversite Öğrencileri Üzerinde Bir Araştırma
}

\author{
DOI: $10.26466 /$ opus.679627
}

*

\author{
Hale Alan* \\ * Dr. Öğr. Üyesi, Akdeniz Üniversitesi, Manavgat Sosyal ve Beşeri Bilimler Fakültesi \\ E-Posta: halealan@akdeniz.edu.tr \\ ORCID: $\underline{0000-0002-2444-1551}$
}

\section{$\ddot{O} z$}

Genç girişimciliği ilk kez bir girişim sürecinde yer alan veya yeni olarak bir işi başlatmış ve yaş olarak genç grubunda bulunan kişiler tarafindan gerçekleştirilmektedir. Tüm dünyada olduğu gibi Türkiye'de de genç girişimciliği son yıllarda stratejik önemi olan bir alan olarak değerlendirilmektedir. Bununla birlikte, birçok farklı konuda projeler geliştirerek sosyal dönüşümü sağlamayı ve sosyal değer üretmeyi amaçlayan sosyal girişimcilik çalışmaları da ülkeler için kalkınma ve toplumsal refahın yükselmesi için önemli bir etkendir. Bu çalışmanın amacı genç girişimciliğinin güncel durumu ve genç girişimciliği engellerinin tespit edilmesi ve son yıllarda çok sık gündeme gelen sosyal girişimcilik kavramı hakkında gençlerin algı ve bilgi düzeylerini belirlemektir. Bu amaçla belirlenmiş araştırma sorularına dayalı olarak yazına katkı sağlamak hedeflenmiştir. Araştırma bir devlet üniversitesinde öğrenim gören 18-35 yaş arası genç nüfus üzerinde yapılmış olup, örneklem olarak seçilmiş 600 öğrenciden yazından derlenerek oluşturulan anket kullanılarak veri toplanmıştır. Sonuç olarak bu araştırma ile üniversite öğrencisi gençlerin girişimciliğe bakışı, girişimcilik hakkındaki fikirleri, girişimcilikten neden çekindikleri ve örnek aldıkları bir girişimci olup olmadığı belirlenmiştir. Genel olarak bulgulara bakıldığında katılımcı gençlerin girişimcilik algılarını engelleyen çok sayıda unsur olduğu görülmüş̧ür. Girişimciliğin sosyal ve toplumsal boyutu olan sosyal girişimcilik hakkında hiçbir bilgi ve fikirlerinin olmaması ise diğer bir araştırma konusu olabileceği değerlendirilmektedir.

Anahtar Kelimeler: Girişimcilik, Genç Girişimciliği, Sosyal Girişimcilik, Gençlik, Üniversite Ö̆ rencisi 


\title{
Youth Entrepreneurship and Social Entrepreneurship: A Research on University Student
}

\begin{abstract}
People who are in the entrepreneurial process, who have started a business for the first time, and who are in the young group as an age group carry out youth entrepreneurship. In recent years, as in the whole world, young entrepreneurship in Turkey has been considered a strategic area recently. However, social entrepreneurship works, which aim to achieve social transformation and generate social value by developing projects on many different subjects, are also progressing as an important factor for the development and promotion of social welfare for countries. This study aims to identify the status of young entrepreneurship and factors hindering young entrepreneurship and to measure the perception and knowledge levels of young people about the concept of social entrepreneurship that has been on the agenda very often in recent years. For this purpose, it is aimed to contribute to the literature based on the research questions determined. The research was conducted on a young population between the ages of 18-35 who were studying at a State University and the data was collected from 600 students selected as samples using a survey compiled from both domestic and foreign literature. According to the results of the research, it was revealed that university students' view of entrepreneurship, their ideas about entrepreneurship, why they are afraid of entrepreneurship and whether they take an example. Considering the findings in general, it is seen that there are many factors that hinder young people's perception of entrepreneurship. The fact that there is no information and ideas about social entrepreneurship, which is the social and social dimension of entrepreneurship, is considered to be another research topic.
\end{abstract}

Keywords: Entrepreneurship, Youth Entrepreneurship, Social Entrepreneurship, Youth, University Student 


\section{Giriş}

Son yıllarda dünya genelinde olduğu gibi Türkiye de girişimcilik, sosyal girişimcilik, inovasyon ve sosyal inovasyon ekosisteminde yaratıcılık ve yenilikçilikle çözümlenebilecek sorunlarla baş etmeye çalı̧̧maktadır. Diğer yandan son yıllarda bu tür sorunlara çözüm bulmak isteyenlerin katılımcıları olduğu programların, yarışmaların, etkinliklerin sayısı giderek artmaktadır. Girişimcilik kavramı ortaya çıan bir ihtiyaç veya sorunu gidermek için yenilikçi iş fikirleri bularak mevcut kaynakları amaçlara ulaşmak için kullanma becerisidir. Adam Smith (1776) Milletlerin Zenginliği (Wealth of Nations) adlı kitabında kapitalist ve girişimciyi aynı kavramlar olarak ele almıştır. Daha sonra 18. yüzyılda girişimcilik kavramı yazında yer edinmiştir. Girişimciliğin önemi 20. yüzyıldan sonra gelişmeye başlamıştır.

Girişimcilik kavramı hakkında yazına bakıldığında üzerinde çok sayıda tanım yapıldığı görülmektedir. Bu tanımların en genel olanında girişimci, her türlü riski göze alan, çevredeki ihtiyaç ve isteklere göre mal veya hizmet üreten kişi olarak tanımlanmaktadır (Bruton, Ketchen ve Ireland, 2013). Girişimcilik ise kaynakları ve mevcut kapasiteyi etkin kullanma faaliyetlerinin tümünü kapsayan bir süreç olarak tanımlanabilir. Dünya'da ve ülkemizde genel olarak kabul görmüş genç ve genç girişimci tanımı yoktur. Öncelikle genç kavramı göreceli bir kavramdır, çünkü kimisine göre genç 18-36 yaş aralığını ifade edebilir, kimisine göre de 15-49 yaş aralığını ifade. Girişimcilik engelleri üzerine yerli ve yabancı yazın incelendiğinde yüzden fazla engel olduğu belirtilmiştir (Jain ve Ali, 2013: 133; Finnerty ve Krzystofik, 1985, s.53). Hatala (2005) tarafından yapılan araştırmada girişimcilerin karşılaştığı en büyük engellerin sırasıyla başarısız olma korkusu, özgüven eksikliği, geleceğin belirsiz olması, kişisel sorunlar, beceri eksikliği, lojistik sorunlar, finansal ve ekonomik ihtiyaçlar ve zaman ayıramama sıkıntıları olduğu belirtilmektedir. Diğer taraftan Choo ve Wong'a (2006) göre girişimcilik engelleri maddi engeller, beceri eksikliği ve güven eksikliği olmak üzere üç boyut altında toplanmıştır. Girişimciliğin engel ve zorlukları makro ve mikro düzeyde ayrı ayrı incelenmiştir. Makro boyuttaki engeller genel olarak devlet yaptırımları, mevcut yasalardaki eksiklikler ve sektörel özellikleri kapsarken, mikro boyuttaki engeller girişimcilerin kendi çevrelerinden ve kişilik özelliklerinden kaynaklandığ vurgulanmıştır (Kutanis, 2006, s.48). 
$\mathrm{Bu}$ çalışmada üzerinde durulan genç girişimciliği kavramı bir girişimci türü olarak son yıllarda yoğun ilgi gören ve odak çalışma konuları arasında olduğu değerlendirilmektedir. Özellikle genç nüfusu fazla olan gelişmekte olan ülkelerde gençlerin girişimciliğe yönlendirilmesi, işsizliğin önlenmesi ve istihdamın artırılması üzerinde çok fazla durulan konuların başında geldiği söylenebilir. Genç girişimciliğinin önündeki engeller de diğer girişimcilik engelleri ile benzerlik göstermektedir. Bu engeller genç girişimcileri korkutmakta ve gelecekte girişimci olmalarını engellemektedir. Aynı zamanda mevcut girişimciler için yeni girişimleri kısıtlayıcı tehdit olarak görülmektedir (Jain ve Ali, 2013, s.91). Bu engelleri tamamen ortadan kaldırmak ya da azaltmak yeni girişimcilerin önünü açacak ve faaliyet halindeki girişimcilere de kolaylık sağlayacağı için önemlidir. Bu nedenle, bu engellerin öncelikle neler olduğunu tespit etmek önce gelir ve daha sonra sebeplerini araştırmak ve başka unsurlarla ilişkilerini incelemek fayda sağlayacaktır. Bu çalışmada üzerinde durulan diğer bir kavram da sosyal girişimcilik kavramı olup, toplumu oluşturan bireylerin, katmanların toplumu ilgilendiren sorunlar için çözüm odaklı bir araya gelmesi olarak tanımlanabilir. Sosyal girişimler dünya genelinde çok sık gündeme gelmekte ve toplumların sosyal ihtiyaçları için, problem çözülene kadar, bir hayat amacı olarak, sürdürülebilir sistemler kuran, yürüten kişilerin kurdukları yapılar olarak karşımıza çıkmaktadır. Sosyal girişimcilik kavramının temel amacı sosyal değer üretmektir.

Bu anlatılanlar doğrultusunda bu çalışmanın amacı bir devlet üniversitesinde öğrenim gören 18-35 yaş aralığındaki gençlerin öncelikle girişimcilik kavramı hakkındaki düşüncelerini, girişimci olma konusundaki eğilimlerini ve sosyal girişimcilik kavramını nasıl algıladıklarını belirlemek daha sonra da genç girişimciliğine karşı engel olarak gördükleri unsurlar hakkında düşüncelerini ortaya çıkarmaktır. Çalışmada cevap aranan üç araştırma sorusu ile hem yazına katkı sağlanması hem de mevcut durumun belirlenmesi hedeflenmiştir.

\section{Kavramsal Çerçeve}

\section{Genç Girişimciliğ i}

Dünya üzerindeki ülkelerin karşılaştıkları ekonomik dalgalanmalar işsizlik oranlarına, kalkınma durumlarına, ekonomik göstergelerin devamlı değişmesine ve insanların ekonomik, sosyal, psikolojik durumlarına ve teknoloji 
ile ilişkilerine yansımakta ve bunların sonucu olarak "girişimcilik" kavramı özellikle son yıllarda üzerinde durulan ve önem verilen bir kavram haline gelmiştir. Son dönemlerde hem dünya genelinde hem de ülkemizde girişimciliğin yaygın olmasının nedenlerine bakıldığında girişimciliğin her bakımdan öneminin ve faydalarının yeni anlaşılmış olması ön plana çıkmaktadır. Dünyanın dört bir yanında hükümetler ve yerel topluluklar refah düzeyini artırmanın ve bölgesel kalkınmaya teşvik etmenin anahtarı olarak, özellikle genç nüfus olmak üzere tüm yaş grubundaki insanların girişimciliğe teşvik edilmesini kabul etmiştir (Chigunta, 2002).

Genç girişimciliği, araştırmacıların, akademisyenlerin ve iş geliştirmeyi amaçlayan uzmanların ilgisini çeken bir konu olmakla birlikte aynı zamanda gelişmekte olan ülkeler için büyük bir endişe konusu haline de gelmiştir (Med ve Lukyamuzi, 2019). Girişimcilerin yerine getirdikleri temel görevler: yeni ürün ve hizmet üretimi, yeni üretim yöntemleri geliştirme, yeni kaynaklar bulmak ve yeni pazarlara girmektir. Çok sayıda girişimci çeşidi bulunmaktadır. Bunlardan genç girişimciliği ilk kez bir girişim sürecinde yer alan ve yeni olarak bir işi başlatmış olan ve de demografik özellik olarak genç grubunda (18-35 yaş arası) yer alan kişiler tarafından gerçekleştirilen girişimciliktir (Chigunta, 2002). Girişimci, bir ihtiyacı teşhis ederek, iş fikrine dönüştüren ve gerekli riskleri üstlenerek, ticari işletme kuran kişi olarak tanımlanır. Bunlardan girişim için gerekli riskleri almak genç yaştaki bireylere zorlayıcı ve korkutucu görünebilir. Günümüzde gençlerin, küresel ekonomiye büyük katkı sağlayacak ve yeni girişimler yaratacak güç ve cesarete sahip olduğu bilinmektedir. Gençlerin çoğunun tüm hayatlarını ve kariyerlerini tek bir işte veya işyerinde çalışarak geçirmeyi düşünmelerini ummak günümüz şartlarında imkânsız görünüyor. Genç girişimciliği yeterince araştırılmayan bir alan olmakla birlikte, verilen önemin giderek dikkat çekmesinin ana nedeni, genç işsizlik oranlarının dünya genelinde artış yönelimli olmasıdır diyebiliriz. Genç işsizliği, son on yılda dünya genelinde aşılması gereken başlıca sosyal ve ekonomik zorlukların başında gelmektedir. Dünya genelinde işsizliğin ortalama 28-33 yaşları arasında artış gösterdiği belirtilmektedir (Gregg, 2001). Diğer taraftan işsizler üretimi ve ekonomik büyüme potansiyelini düşüren önemli bir atıl durumda ekonomik kaynak stoğunu temsil etmektedir (Gregg, 2001). Bu sorunun çözümü için girişimcilik, çok iyi eğitilmiş gençlerin yeteneklerini keşfetmeleri ve iş zekâsı kazanmaları için bir araç olarak görülmektedir. 
En başarılı yeni iş girişimlerinin gençlerden, hatta çok genç yaştaki bireylerden geldiği fikri yaygındır. Genç insanların genellikle mevcut düşünceye daha az dikkat ettiği ve dolayısıyla daha doğal ve yenilikçi olduğu düşünülmektedir. Çocuk sorumluluğu ve aile geçindirme gibi ailevi sorumlulukları olmadığından gençler daha çok zaman ve enerjiye sahiptir. Gençlerin girişimcilikte daha yetenekli ve başarılı olacağı düşüncesinin baskın olduğu söylenebilir. Dünya genelinde genç girişimcilerin sahip oldukları etkileyici hayat hikâyelerinin onları başarıya teşvik ettiği görülmektedir. Ekonomik zorluk ve imkânsızlıklar nedeniyle okuldan ayrılmak zorunda kalmış ve sonrasında bir arkadaş grubuyla yeni bir iş kurmanın peşine düşmüş gençlerin sayısı azımsanmayacak kadar çoktur. Örneğin, Silikon Vadisi'nde girişim kapitalistleri, daha genç kuruculara yatırım yapma konusunda belirgin bir önyargı sergilerler ve genellikle eski kurucuları dışta bırakırlar. Gençlik ve başarı arasındaki algılanan bağlantı o kadar yaygın ki, bazı teknoloji çalışanlarının daha genç görünmek için estetik ameliyat yaptırdıkları da sosyal medyada rastlanan haberlerdendir.

Küresel ekonomi şartları, gençlerin işgücüne yalnızca üniversite diplomasına sahip olarak değil, aynı zamanda her iş veya endüstride başarılı olmalarına yardımcı olabilecek insiyatif alma, sorunları eleştirel bir şekilde çözme ve etkili iletişim kurma becerisini içeren bir dizi girişimcilik becerisi ve tutumuna sahip olmaların gerekli kılmaktadır. Bunları ve girişimcilik zihniyetinin bir parçası olan diğer becerileri öğrenerek, kariyere hazır olmak önemlidir. Sonuç olarak, girişimci düşünme gençliği geleceğe hazırlamakla ilgilenen birçok kuruluş için kilit hale gelmiştir.

Gençleri girişimciliğe teşvik ederek, kaynak ve fırsatlar sağlayan çok sayıda Avrupa Birliği programı ve girişimcilik ağı projesi bulunmaktadır. Avrupa Genç İşletmeciler Konfederasyonu (European Confederation of Junior Enterprises-JADE) ${ }^{1}$ ve Avrupa Genç Girişimciler Konfederasyonu (European Confederation of Young Entrepreneurs) ${ }^{2}$ genç insanlar adına konuşmayı ve gençleri ekonomik ve politik hayata katılmaları için teşvik etmeyi amaçlayan iki ana organizasyondur. Avrupa Sosyal Fonu (ASF-The European Social Fund), Avrupa Bölgesel Kalkınma Fonu (ABKF-European Regional Develop-

\footnotetext{
${ }^{1}$ https://www.jadenet.org/

${ }^{2}$ http://www.yesforeurope.eu/
} 
ment Fund) tarafından doğrudan genç girişimcilere veya gençlik girişimciliğini ve serbest meslek desteğini teşvik etmek için çalışan bölgesel kuruluşlara finans sağlayan programlar ve ağ faaliyetleri bulunmaktadır. 2010'da Avrupalı gençlerin eğitimini ve istihdam edilebilirliğini artırarak gençlerin işsizliğini azaltma stratejisinin bir parçası olarak başlatılan ASF programı "Hareket Halindeki Gençlik"3 dâhil Avrupa çapında ASF ve ABKF tarafından finanse edilmektedir. Bu programın çalışma yöntemi, Avrupa'da çalışmak, öğrenmek, eğitilmek ve iş bulmak için gençler arasında uluslararası bir hareketlilik oluşturmak ve $A B$ ve ulusal düzeyde tespit ve eylemde bulunma politikalarını koordine etmektir. Genç girişimciler için Erasmus ${ }^{4}$, proramının bileşenleri özellikle Avrupa'da küçük bir işletme kurma veya yönetme becerisine sahip gençleri hedeflemektedir. Tecrübeli girişimcilerin çalışmaları ile bilgi ve iş fikirlerini yeni girişimcilere aktarmalarını hedeflemektedir.

Gençlik Girişimcilik Stratejileri ${ }^{5}$, bölgesel ekonomik büyümeyi hızlandırmak için gençlerin girişimcilik faaliyetlerini desteklemeyi amaçlamaktadır. Öğrencileri "Avrupa Öğrenci Girişimleri Yarışması” gibi iş hayatına taşımayı hedefleyen yarışmalarda düzenlenmektedir. Bazı programlar hizmetlerini internet üzerinden sunar. Örneğin, eğitim almak isteyen gençleri başka bir ülkedeki eğitim, burs, staj imkânlarıyla ilişkilendirmek için çevrimiçi hizmet sunan "Hareket Halindeki Gençlik" programına benzer şekilde, "Gençlik işte" (Youth@Work) programı aynı zamanda uluslararası hareketliliğe ve gençler arasında bilgi alışverişine katkıda bulunmayı amaçlamaktadır. $\mathrm{Bu}$ kuruluşların, ağların ve programların amacı ulusötesi, ulusal ve yerel düzeylerde gençlik girişimciliği ile ilgili, Avrupa çapında bilgi ve öğrenme ağları oluşturmak, genç girişimciler arasında bilgi alışverişi, deneyim ve en iyi uygulamaları oluşturmak, işbirliğini teşvik etmek, genç girişimciliği konusunda araştırma yapmak, sınır ötesi değişim programları hazırlayarak bölgesel politikaları gözden geçirmektir. Ayrıca, öğrencileri ve mezunları işgücü piyasasına ve Avrupa'daki genç girişimcilerin (18-30 yaşındaki öğrenciler) önderlik ettiği "EntEx" gibi girişimcilik faaliyetlerine ${ }^{6}$ bütünleştirmek için desteklemeye çalışan çok sayıda kuruluş ve girişim vardır.

\footnotetext{
${ }^{3}$ http://ec.europa.eu/youthonthemove/index_en.htm

${ }^{4}$ https://www.erasmus-entrepreneurs.eu/page. php?cid=2\#.U2vOFIFdVYU

${ }^{5}$ https://ec.europa.eu/social/main.jsp ?langld=en\&cat/d $=836$

${ }^{6}$ http://ent-ex.eu/\#!partners/c224u
} 
Üniversite ortamında kurulan işletmeler ile ilgili yazında, fakülte personeli tarafindan yeni teknolojilerin ticari kullanımı yoluyla kurulan akademik firmalar olarak bilinen "spin-off" firmalar ile öğrenciler tarafından kurulan firmalar (student spin-off) arasında bir fark vardır. Öğrenci sirketi olarak bilinen firmalar öğrencilerin lisans derslerinde edindikleri ticari bilgileri uyguladıkları çalışmaları kapsar (Mosey, Noke ve Binks 2012). Yaşam tarzı şirketler olarak görülmesine rağmen, öğrenci kesintileri hem mutlak sayılar hem de kalite açısından en önemli spin-off şirketidir. Amerika Birleşik Devletleri'ndeki Massachusetts Teknoloji Enstitüsü'nde (MIT), öğrencilerin kurucusu olduğu şirket sayısı akademi üyelerinin kurduğu şirketleri aştığı görülmektedir (Astebro, Bazzazian ve Braguinsky, 2012). Ayrıca, Amerika Birleşik Devletleri'ndeki en önemli 100 araştırma kurumuna göre, fakülte personelinin kurucusu olduğu şirketlerinin sayısı çok azdır ve yeni mezunların öğretmenler ve araştırmacılara kıyasla yeni şirketler yaratma ihtimalinin iki katı fazla olduğu belirtilmektedir (Astebro, Bazzazian ve Braguinsky, 2012). Bu nedenle, öğrenciler tarafından oluşturulan şirketlerin sayısı akademisyenler tarafından oluşturulanların sayısından çok daha fazladır. Bununla birlikte, üniversite kuluçka merkezlerine yönelik araştırmaların çoğu, yalnızca akademisyenlerin ve araştırmaciların oluşturduğu şirketler olan akademik bölümlere odaklandığı belirtilmektedir (Mosey, Noke ve Binks 2012).

Genç girişimciliğinin şimdiye kadar yeterince araştırma konusu olmamasının iki önemli nedeni bulunmaktadır. İlk neden üniversitelerin öğrenciler tarafından yeni girişimler kurulmasını desteklemede zayıf bir anlayışa sahip olması ve diğer neden ise yürürlükteki girişimcilik politikalarının öğrencilerin oluşturduğu şirketleri kapsamlarının bir parçası olarak görmede yetersiz kalmasıdır. Bu nedenle, üniversitelerde ve özellikle de öğrencilerinin kurduğu ve yürüttüğü girişimcilik faaliyetlerinin çoğu yeterince önemsenmemektedir (Astebro vd., 2012). Ayrıca, girişimci ekosistemlerin gençler tarafından oluşturulan işletmeler için nasıl geliştirildiğine dair çok az bir yazın vardır (Wright, Siegel ve Mustar, 2017). Öğrenci girişimciliği ile ilgili yazının çoğu özellikle girişimcilik eğitimine odaklanmakta ve öğrencilerin yeni işletmeler yaratma şeklindeki bağlamsal etkilerini göz ardı etmektedir (Bergmann, Hundt ve Sternberg. 2016). Girişimcilik genç insanlar için, özellikle yoksulluk bağlamında ve genç işsizliği ile mücadelede bir yol olarak önemli bir güçlendirme faktörü olarak değerlendirilmektedir (Bruton, Ketchen ve Ireland, 2013; Dash ve Kaur, 2012). Hem kamu hem de özel sektörün desteği 
gençler tarafından oluşturulan küçük işletmelerin sürdürülebilir büyümesi için çok önemlidir (Nasser, Du Preez ve Herrmann, 2003). Gerekli desteklerin sağlanması çok önemlidir, çünkü girişimcilik olgusu ülke düzeyinde belirgin bir öneme sahip olsa da, bölgesel düzeyde sorunlar çözülmezse girişimciliğin etkinliği azalmaktadır (Acs, Autio ve Szerb 2014). Genç girişimciliğini geliştirme sürecinde belirsiz hedeflerin ve zayıf kontrol mekanizmalarının kaldırılması ile birlikte yerel paydaşların yanı sıra daha geniş bir toplum dâhil olmak üzere tüm paydaşların katılımlarının arttıılmasını teşvik etmek etkilidir (Arshed, Carter ve Mason, 2014).

\section{Genç Girişimciliğinin Önündeki Engeller}

Genç girişimciliğinin önündeki engeller ile girişimciliğin önündeki engeller hemen hemen aynı olsa da genç girişimcilerin ya da genç girişimci adaylarının daha fazla engelle karşılaştığı ve bunun sonucu olarak da genç girişimci sayısının az olduğu söylenebilir. Son zamanlarda gençlerin kaliteli iş bulma veya kendi işlerini kurma konusundaki yaşadıkları zorlukların farkına varılmış ve inceleme konusu yapılmıştır. Gelişmekte olan ülkelerdeki olumlu ekonomik büyüme belirtilerine rağmen, genç işsizliği ve istihdam sıkıntıları devam eden ve artan zorlukların başındadır. Türkiye dünya genelinde en genç nüfusa sahip ülkelerden biri olarak bu zorlukların üstesinden gelme konusuna özellikle önem vermelidir. Genç ve dinamik nüfus özelliğine sahip olan Türkiye için bu insanları nitelik kazandırarak ve onları girişimciliğe yönelik olarak en iyi şekilde eğiterek, bu potansiyelini en iyi şekilde değerlendirmenin yollarını aramalıdır. Genç girişimciliği bireyin içinde bulunduğu sosyoekonomik ve kültürel yapı ile şekillenmektedir. Aile, toplumsal davranış örüntüleri, eğitimin kalite ve düzeyi ile genel ekonomik koşullar, bireyin girişimcilik ruhunu geliştirmesini ve sahip olduğu girişimci niteliklerini olumlu ya da olumsuz etkileyebilmektedir (Yetim, 2014:80). Kayıtlı istihdam olanaklarının bulunmamasına cevap olarak, Türkiye'deki gençlerin çoğu kayıt dışı sektöre dönüşmekte ve mikro işletmelerde istihdam aramaktadır veya kendi küçük işletmelerini zorlukla kurmaktadır. Genel olarak bakıldığında istihdamı ve mikro işletmelerin kurulmasına engel olan en önemli ve en yaygin yaşanılan zorluklar şunlardır;

1. Büyümeyen ve ilerleme kaydedemeyen işletmeler: Bu işletmelerin büyüme hızı çok azdır. Bu sektördeki birçok girişimci başarılı olmak için 
gerekli güce ve enerjiye sahip olsa bile, krediye erişimin yetersiz olması ve iyi yönetim uygulamalarının sınırlı olması gibi engeller nedeniyle işleri kötü durumdadır. Bu durumdaki sektörlerdeki işletmeler daha fazla genç istihdamı ve girişimciliği için fursat yaratma ve yeni işletmeler kurulması konusunda potansiyele sahip değildir.

2. Yetenek ve bilgi yetersizliği: Büyüyen sektörlerdeki işletmeler, bir çalışan olarak başarılı olmak için doğru beceri ve davranışlara sahip personeli işe almak ve bunları tutmakta zorlanmaktadır. Büyüme yaşayan girişimcilerin önündeki en büyük engellerden biri, mükemmel işler sunmak için yetenek ve bilgisine güvenebilecekleri personeli bulmaktır.

3. Gelişmekte olan girişimcilere destek eksikliği: Yeni girişimci olarak kayıt dışı sektöre giren gençler, girişimlerini başarılı bir şekilde gerçekleştirebilmeleri için gereken bilgiye sahip değillerdir (bilgi, tecrübe, zihin kurgusu vb.). Gençleri girişimciliğe yönlendirecek ve destekleyecek tecrübeli ve bilgili destekçilerin olmaması çözülmesi gereken sorunların başında gelmektedir (Arshed, Carter ve Mason, 2014; Buchert, 2014; Hayes ve Richmond, 2017).

Ülkemizde girişimcilerin karşılaştıkları engellerin başında kamu teşviklerinin az olması gelmektedir. Bununla birlikte genç girişimciliğinin belli başlı karşılaştı̆̆ı engeller; girişimcilik eğitiminin eksikliği veya yetersiz olması, gençlerin yeterli sermayeye sahip olmamaları, gerekli yetenek ve sorumluluğa sahip olmamaları, girişim yapılacak iş fikrine sahip olunmaması, aile ve çevre desteğinin olmamasıdır (Pihie ve Akmaliah, 2009).

Girişimcilik eğitimi Amerika Birleşik Devletleri başta olmak üzere tüm dünyada giderek yayginlaşmaktadır. Bu büyümenin büyük kısmı, son on yılda girişimcilik merkezlerinin ve kulüplerinin sayısının oldukça arttığ 1 kolej ve üniversite düzeyinde gerçekleşmiştir. Girişimcilik programları aynı zamanda geleneksel işletme bölümlerinin dışında büyümekte ve üniversiteler arasında işlevselliği arttırmaktadır. Avrupa Birliği girişimciliği sekiz yaşam boyu öğrenme yeterliliğinden biri ve bilgi temelli bir toplum için gerekli olan bir unsur olarak tanımlamasından yola çıkarak okullarda girişimcilik eğitimini teşvik eden girişimcilik çalışmalarını tüm paydaşlar arasında fikir birliği sağlamayı ve eğitim ve iş dünyası arasında bir köprü oluşturmayı amaçlamaktadır (Moberg, 2012). 
Gençler girişimcilik eğitimine sahip olsalar bile farkında olmadıkları ya da dikkate almadıkları engeller nedeniyle girişimciliğe yönelemeyebilirler. Girişimci gençlerin oranı, engeller ve fırsatlar ile işgücü piyasası koşullarındaki farklılıklar nedeniyle ülkelere göre değişmektedir. Her ülkenin tarihsel gelişimindeki farklılıklardan ötürü meydana gelen sosyal, ekonomik, teknolojik ve politik yapılar gibi farklılıklar nedeni ile bir ülkede girişimciliği açıklayan faktörler diğer ülkeler için geçerli olmayabilir. Gelişmiş ülkelerde gençlerin girişimcilik seviyelerinin yüksek olması daha muhtemeldir. Bunun yanı sıra ücretli istihdam olanaklarına sahip işgücü piyasalarına sahip gelişmiş ülkelerde, girişimciliğe teşvik etme oranı daha az olabilir ve bu nedenle bu ülkeler düşük girişimcilik seviyelerine sahip olabilir. Tüm bunlara rağmen genç girişimciliğine yönelik toplumsal bakış açısı da belirleyici bir faktördür.

Genç girişimcilerin girişimcilik faaliyetlerine bakıldığında benzer özelliklere sahip olma eğilimlerinin yanı sıra, genellikle farklı yaklaşımlara ve farklı işletme türlerine sahip oldukları görülmektedir. Genç girişimcilerin genellikle yetişkinlerden daha küçük işletmeleri tercih ettikleri söylenebilir. Gençlerin işlettiği işletmelerin, inşaat, bilgi ve iletişim teknolojileri şirketleri gibi sektöre girişin kolay olduğu ve düşük sermaye gereksinimlerine karşı engelleri düşük olan bazı sektörlerde yoğunlaştı̆̆ ve dar ürün gruplarına odaklanma eğilimi daha yüksek olduğu görülmektedir. Buna göre, birçok genç girişimci, yalnızca tanıdık olmaları nedeniyle ve diğer pazarlardaki fırsatlar ve bunlardan nasıl yararlanılacağı konusunda bilgi sahibi olmadıkları için yalnizca yerel pazarlara odaklanmaktadır (Chigunta, 2002).

Özetle, gençlerin iş fikirlerini hayata geçirecek projelere dönüştürmesini engelleyen unsurlarla karşı karşıya olduğu görülmektedir. Bu engellerin başlıcaları, sosyal tutum, beceri eksikliği, yetersiz girişimcilik eğitimi, iş tecrübesi eksikliği, sosyal ağ ve bağlantı eksikliği ve pazar engelleri alanlarında ortaya çıkmaktadır. Gençler, aileleri, öğretmenleri ve bir bütün olarak tüm toplumsal paydaşlardan etkilenir. Ebeveynler ve öğretmenler gibi önemli rol modelleri, girişimcilik gereksinimlerinin ve fırsatlarının genellikle farkında değildir. Bu farkındalık eksikliği, girişimcilik faaliyetlerinin teşvik edilmemesine veya hatta genç girişimciliğine engel teşkil eden olumsuz sosyal tutumlara yol açmaktadır. Eğitim ve öğretim programlarının girişimci tutum ve becerileri kazandırmak ve geliştirmek için yeterli olmaması, ancak bu alandaki bazı gelişmelere rağmen öğrencileri ücretli istihdam olarak hazırladıkları halen tartış1lmaktadır (Potter, 2008). Önceki iş ve girişimcilik deneyimi, iş kurma ve 
girişimcilik performansının önemli bir belirleyicisidir. Gençler genellikle yeni bir iş kurmak ve başarılı bir şekilde işletmek için gerekli olan insani, finansal ve sosyal sermayeden yoksundur. Bu nedenle, işlerini kurmak veya işletmek için gerekli becerilerden yoksun olabilirler. Daha büyük finansal kaynaklara sahip girişimcilerin başarılı olma olasılıkları daha yüksektir. Gençler dezavantajlı durumdalar, çünkü bankalar, kredi geçmişi, geçmiş iş performansı ve teminat gibi kredi tekliflerinin değerlendirilmesinde bir dizi parametre uyguladığından, dış finansman elde etmeyi yetişkinlerden daha zor sağlarlar. Gençlerin muhtemelen sınırlı iş ağları ve işle ilgili sosyal sermayeleri vardır. Bu durumun işlerini kurmak ve işletmek için olumsuz sonuçları olabilir. Piyasa engelleri ayrıca genç girişimciliğini de çok yakından etkilemektedir. Finansal piyasalar, genç girişimciliğini desteklemede önyargilı olabilir. Yukarıdaki engellerin birbiriyle ilişkili olduğuna dikkat etmek ayn derecede önemlidir; bu tek bir seferlik bir çözümden ziyade bir politika araçları paketine duyulan ihtiyacı ifade eder.

\section{Sosyal Girişimcilik}

Sosyal girişimcilik kavramının gelişmiş ülkelerden gelişmekte olan ülkelere doğru hızla akmakta olan bir akım olarak girişimcilik çalışmalarına yeni bir boyut kazandırdığı söylenebilir. Özellikle gelişmekte olan ülkelerde toplumsal sorunların çözüm bulması ve olumsuz şartların düzeltilmesi amacıyla halkın ve sivil toplum kuruluşlarının bu olumsuzlukları iyileştirmek için ticari fayda ummadan gerçekleştirdikleri faaliyetleri kapsamaktadır. İşletmelerin ve kurumsal firmalarında bu çalışmalara destek vermeye başlamasıyla birlikte giderek yaygınlaşmaya başlamıştır. Sosyal girişimciliğin en önemli isimlerinden biri "mikro kredi" kavramını bulan Bangladeşli akademisyen ve bankacı olan Muhammed Yunustur. "Grameen Bank" isminde kurduğu banka ile yoksullara 30-40 dolara denk gelen desteklerle küçük işler kurmasına sebep olmuştur. Bu yardımdan faydalananların sayısı azımsanmayacak kadar fazladır. Sadece 2016 yılı verilerine göre gelişmekte olan ülkelerde 170 milyon kişi mikro krediden faydalanmıştır.

Sosyal girişimcilik kavramının, sosyal sorumlulukla karıştırılmaması gerekmektedir. Çünkü her ikisi birbirini destekleyen kavramlar olsa da birbirinden çok farklıdır. Sosyal sorumluluk kuruluşların alacakları kararların 
toplumu nasıl etkileyeceğine odaklanan çalışmalar yaparken sosyal girişimcilik ise sosyal sorumluluk faaliyetlerini tamamlamaya odaklanan geniş çaplı çalışmaları barındırır. Sosyal girişimcilik insanları fakirleştiren toplumsal kaynaklı şartları değiştirmeye veya iyileştirmeye odaklanan pratik, yenilikçi ve toplum odaklı yaklaşımları ifade eder. Bu bağlamda sosyal girişimciliğin tamamlayıcı özelliklerinin başında küresel, ulusal veya bölgesel düzeyde yaşanılan toplumsal sorunlara sürdürülebilir çözümler bulunması, toplumsal sorunların hızlı bir şekilde fark edilmesi ve çözümüne yönelik işbirliği, dayanışma ve farklı taraflar arasında beyin fırtınası ile öneriler geliştirilmesi gelmektedir.

Sosyal girişimciliğin birbirinden farklı birçok tanımında anlam karmaşasına maruz bırakıldığı belirtilmektedir (Trexler, 2008). Kavram hakkında ortak bir tanım veya anlam eksikliği konuyla ilgili bilimsel araştırmaların ilerlemesinin önündeki en büyük engellerden biridir (Zahra, Gedajlovic, Neubaum ve Shulman, 2009). Muhasebe, ekonomi, girişimcilik ve siyaset bilimi gibi farklı disiplinlerle ilgili bilim adamlarından çok sayıda tanım ortaya atılmıştır (Short, Moss ve Lumpkin, 2009). Tanım çokluğu ve anlam karmaşasına rağmen sosyal girişimcileri normal girişimcilerden ayıran özellikler belirgin olarak ortaya çıkmaktadır. Bir sosyal misyonun baskınlığı hissedilmeli, sosyal girişimcilik örgütlerinin açk ve yerleşik bir sosyal amacı olmalıdır. Sosyal girişimcilerin doğrudan mevcut ekonomik veya sosyal kurumlar tarafından karşılanamayan temel insan ihtiyaçlarını doğrudan karşılayan ürün ve hizmetler geliştirmesi anlamina gelmektedir (Seelos ve Mair, 2005, s.243-244).

Normal girişimcilikten farkı, sosyal girişimcilerin sosyal değer yaratılmasında öncelikli olduğu, girişimciliğin ise ekonomik değer yaratmanın finansal olarak uygulanabilirliğini sağlamak için gerekli bir koşul olduğudur (Mair ve Martı, 2006:38). Kar amacı güden bir firmanın amacının müşterileri için üstün değer yaratmak iken sosyal girişimcinin öncelikli misyonunun müşterileri için üstün sosyal çözüm yaratmak olduğu ifade edilmektedir (Dees, 1998).

Şu anda ülkeler arasında sosyal girişimciliğin yaygınlığı kapsamındaki farklılıklarla ilgili bir araştırma bulgusuna rastlanmamıştır. Birkaç görüş öne sürülmüş olsa da, bu görüşleri ispatlayacak anlamlı veri sağlanamamıştır. Sosyal girişimcilik, tanım gereği devlet, sivil toplum veya toplum tarafından yeterince çözülmeyen yoksulluk, çevresel sorunlar, yolsuzluk, eğitim veya 
sağlık hizmetlerinin yetersizliği ve savaş gibi sosyal sıkıntıları ele alan bir faaliyet olduğu için gelişmiş ülkelerde sosyal girişimciliğin daha yüksek düzeyde olması beklenir. Öte yandan, farklı bir görüşte, daha büyük düzeydeki sosyal sorunlarm bir sonucu olarak, insanların hayatta kalmaya daha fazla dikkat etmesi gerektiği ve bu nedenle de kendilerini sosyal girişimlerin üzerinde normal girişimciliği destekleyen yani finansal olarak kar sağlayan bir bağlamda bulmaları gerektiği yönündedir. Bunun için gelişmekte olan ülkelerde sosyal girişimciliğin yaygınlaştırılması ve geliştirilmesi gerekmektedir (Bosma ve Levie 2010). Yazına bakıldığında sosyal girişimciliğin henüz yeni bir kavram olduğu, araştırılması ve geliştirilmesi gereken çok fazla boşluğun olduğu dikkat çekmektedir. Gelişmekte olan ülkelerde normal girişimciler için çalışmalar yeni yeni belirli bir düzeye ulaşmıştır. Bu nedenle gelişmekte olan ülkelerde daha az sosyal girişimci bulunması normal karşılanması vurgulanmıştır (Smith ve Stevens, 2010).

\section{Genç Girişimciliği Üzerine Yapılmış Çalışmalar}

Ülkemizde araştırmacıların, uzmanların ve akademisyenlerin son yıllarda yoğun olarak odaklandığı konuların biri genç girişimciliği olduğu söylenebilir. Genç girişimciliğiyle ilgili yapılmış çalışmalar incelendiğinde çoğunda üniversite öğrencilerinin girişimcilik eğilimleri ve bu eğilimlerini etkileyen faktörlerin araştırıldığı görülmektedir. Gençlerin girişimcilik eğilimleri ile ilişkilendirilen değişkenlerin başında demografik özellikler ve sosyo-kültürel farklılıklar gelmektedir (Örücü vd., 2007; Kayalar ve Ömürbek, 2007; İpçioğlu ve Taşer, 2009; Y1lmaz ve Günel, 2011; Solmaz vd., 2014; Yüksel vd., 2015; Salik ve Kaygın, 2016; Hancioğlu ve Tekin, 2018; Arslan, E., Kendir ve Türkmen, 2018).

Girişimcilik eğilimini araştıran çalışmaların fazla olmasının nedeni Hancıŏ̆lu ve Tekin'e (2018) göre gençlerin bireysel girişimcilik eğiliminin açık bir tanımının yapılmamış olması ve ölçümü için sistematik ve güvenilir olarak türetilmiş bir ölçüm sisteminin geliştirilmemesidir. Bundan dolayı araştırmalar girişimcilikle ilgili mikro ve makro çevre koşulları, bireysel bilgiler, kişilik özellikleri, kişisel durumların tanımlanma süreci üzerine odaklanmıştır (Hancıoğlu ve Tekin, 2018). Girişimcilik eğilimini ölçmek amacıyla ölçekler geliştirilmiş (Thompson, 2009; Koh, 1996; Autio vd., 2001; Yılmaz ve Sünbül, 
2009) ve araştırmalarda çoğunlukla bu ölçekler kullanılmıştır. Tiftik ve Zincirkıran'ın (2014) çalışmasında Yılmaz ve Sünbül'ün (2009) geliştirdiği üniversite öğrencilerinin girişimcilik eğilimi ölçeği kullanılmış ve girişimcilik eğiliminin kendine güven, fırsatlardan yararlanma, risk alma, kontrol odağı, karar verme, yenilikçilik, başarma ihtiyacı olmak üzere yedi alt boyutu belirlenmiştir. Bu çalışmaların dışında genç girişimciliğiyle farklı değişkenleri ilişkilendiren çalışmalarda ortaya çıkan sonuçlar dikkat çekici niteliktedir. Hancıoğlu ve Tekin'in (2018) araştırmalarında girişimcilik özelliklerinden özellikle yenilikçilik boyutunun günümüz bilgi çağında oldukça önemli olduğu düşünüldüğünde genç girişimci adaylarının bu bilincinin arttırılması gerektiği belirtilmiştir. Uygun, Mete ve Güner'in (2012) çalışmalarında gençlerin girişimcilik eğilimi ile girişimci kişilik özellikleri arasındaki ilişkiler incelenmiştir. Benzer olarak Sarıtaş ve Duran (2017) üniversite öğrencilerinin girişimcilik eğilimini etkileyen kişisel özellikleri, aile yapıları, toplum kültürü ve aldıkları eğitimin etkisini araştırmışlardır. Yazına bakıldığında gençlerin girişimciliğe yakınlıkları, girişimcilik engelleri ile ilgili düşünceleri ve sosyal girişimcilik ile ilgili bilgilerini belirlemeye yönelik algı ve düşünce ölçmeye yönelik bir çalışmaya rastlanmamıştır. Bu nedenle bu çalışmanın genç girişimciliğini hem kavramsal hem de araştırma yöntemi olarak farklı bakış açısıyla değerlendirdiği söylenebilir.

\section{Yöntem}

Bu araştırmanın amacı, Türkiye' nin en küçük şehrindeki Bayburt Üniversitesinde okuyan gençlerin girişimcilik kavramına ait düşüncelerini, girişimciliğinin önündeki engellerin belirlenmesine ve sosyal girişimcilik hakkındaki bilgi düzeylerini ölçmektir. Araştırmada nicel araştırma yöntemi kullanılmış olup, veri toplama aracı olarak hazırlanan anket formu hem oluşturulan bağlantı ile internet üzerinden hem de elden dağıtılmıştır. Anket formu oluşturulurken gerekli yazın taraması yapılarak girişimcilik kavramı, ülkemizdeki girişimcilik engelleri ve sosyal girişimciliğin durumunu belirlemeye yönelik sorulara yer verilmiştir. Çalışmada kullanılan ve sadece bu araştırma için hazırlanan anketin birinci bölümünde yer alan ilk yedi soru anket formunu yanıtlayan öğrenciler hakkında tanımlayıcı ve demografik bilgileri içermektedir. Bu sorular araştırmaya katılanların yaşı, cinsiyeti, bölümü, ailelerinin sos- 
yal ve ekonomik durumlarına ilişkin sorulardır. Anketin ikinci bölümü araştırma amacına ve araştırma sorularına cevap aramak doğrultusunda yirmi yedi adet soruyu kapsamaktadır. Anketin son bölümünde sosyal girişimcilik algısını belirlemek amacıyla beş soru bulunmaktadır. Son bölümde öğrencilerin açık uçlu sorulardan oluşan ankete verdikleri cevaplar, nitel araştırma yöntemlerinden sistematik analiz ve betimsel analiz yöntemleri kullanılarak değerlendirilmiştir. Rastgele örnekleme yöntemi kullanılarak, 600 öğrenci araştırmaya katılmıştır. Elde edilen verilerin istatiksel analizleri için SPSS programından faydalanılmıştır. Bu çalışma ile cevap aranan araştırma soruları şu şekildedir:

- Girişimcilik kavramı hakkında gençlerin bilgi düzeyi ne kadardır?

- Genç girişimciliği kavramının önündeki engeller nelerdir?

- Sosyal girişimciliği tanımlayan en önemli öğeler ve bilinen sosyal girişimcilik örnekleri nelerdir?

\section{Bulgular}

Tablo 1. Katılımcılarn Demografik Özellikleri

\begin{tabular}{lll}
\hline Açılama & Frekans & Oran (\%) \\
\hline Yaş & & 70 \\
\hline 18-24 Aralığı & 420 & 30 \\
\hline 25-29 Aralığı & 180 & 100 \\
\hline Toplam & 600 & \\
\hline Cinsiyet & & 33,5 \\
\hline Kadın & 201 & 66,5 \\
\hline Erkek & 399 & 100 \\
\hline Toplam & 600 & \\
\hline Fakülte/Yüksekokul & & 22 \\
\hline İ̈BF & 132 & 34 \\
\hline Mühendislik & 204 & 14 \\
\hline Eğitim & 84 & 15 \\
\hline Meslek Yüksekokulu & 90 & 5 \\
\hline İlahiyat & 30 & 5 \\
\hline Sağlık Bilimleri & 30 & 5 \\
\hline Beden Ĕ̆itimi ve Spor & 30 & 100 \\
\hline Toplam & 600 & \\
\hline
\end{tabular}

Verilere frekans ve sıklık analizleri yapılmış ve sonuçlara ulaşılmıştır. Araştırmaya katılan 600 öğrencinin demografik özellikleri frekans analizi yapılarak incelenmiştir. Analizlere göre öğrencilerin yaşları incelendiğinde 
\%70'ının 18-24, \%30'unun 25-29 yaş aralığında olduğu tespit edilmiştir. Cinsiyet açısından bakıldığında katılımcıların \%66,5'i erkek ve \%33,5'inin kadın olduğu görülmüştür. Öğrencilerin eğitim gördükleri bölümlere bakıldığında \%22'sinin İ̈BF, \%34'ünün Mühendislik Fakültesi, \%14'ünün Eğitim Fakültesi, \%15'inin Meslek Yüksek Okulu, \%5'inin İlahiyat Fakültesi, \%5'inin Sağlık Bilimleri Fakültesi ve \% 5'inin Beden Eğitimi Yüksek Okulunda okudukları belirlenmiştir. Katılımcıların demografik özellikleri oranları Tablo 1'de gösterilmektedir.

Katılımcıların \%16'sına göre genç girişimciliğin önündeki en önemli engel bilgi sahibi kalifiye personel bulamamadır. \%32'lik ve en büyük kesim ise sermaye ve kredi bulamamayı en önemli engel olarak görmektedir. Özellikle girişimcilik eğitimi eksikliği \%15, başarısız olma korkusu ise \%12 oranındadır. $\% 15$ 'si bürokratik engelleri, \%10'u ise girdi maliyetlerini en önemli engel olarak görmektedir. Genç girişimciliğinin önündeki en önemli engellere ait oranlar Tablo 2'de gösterilmiştir.

Tablo 2. Genç Girişimciliğinin Önündeki En Önemli Engeller

\begin{tabular}{lll}
\hline Engeller & Frekans & Oran (\%) \\
\hline Sermaye ve Kredi Bulamama & 192 & 32 \\
\hline Nitelikli Eleman Eksikliği & 96 & 16 \\
\hline Girişimcilik Eğitimi Eksikliği & 90 & 15 \\
\hline Bürokratik Engeller & 90 & 15 \\
\hline Başarısız Olma Korkusu & 72 & 12 \\
\hline Girdi Maliyetleri & 60 & 10 \\
\hline Toplam & 600 & 100 \\
\hline
\end{tabular}

Katılımcıların \%50'si girişimcilik kavramı hakkında bilgi sahibi iken \%25'lik kesim girişimcilik kavramı hakkında bilgi sahibi olmadığını belirtmiştir. \%25'lik kesim ise girişimcilik hakkındaki bilgilerinin az miktarda olduğunu belirtmişlerdir. Girişimcilik kavramı hakkında bilgi sahibi olma oranları Tablo 3' de gösterilmiştir.

Tablo 3. Girişimcilik Kavramı Hakkında Bilgi Sahibi Olma

\begin{tabular}{lll}
\hline Açılama & Frekans & Oran (\%) \\
\hline Bilgi Sahibi Olan & 300 & 50 \\
\hline Az Miktarda Bilgi Sahibi Olan & 150 & 25 \\
\hline Bilgi Sahibi Olmayan & 150 & 25 \\
\hline Toplam & 600 & 100 \\
\hline
\end{tabular}


Gençlerin sadece \%10’u girişimcilik eğitimlerini yeterli bulmakta olup, özellikle girişimcilik eğitim programlarının artırılması ve mevcut eğitimlerin daha iyi gerçekleştirilmesi gereğini vurgulamışlardır. Girişimcilik eğitimlerini yeterli bulma oranları Tablo 4'de gösterilmiştir.

Tablo 4. Girişimcilik Eğitimlerini Yeterli Bulma

\begin{tabular}{lll}
\hline Açılama & Frekans & Oran (\%) \\
\hline Yeterli Bulan & 60 & 10 \\
\hline Yeterli Bulmayan & 540 & 90 \\
\hline Toplam & 600 & 100 \\
\hline
\end{tabular}

Araştırmaya katılanlar üniversite öğrencilerinin nerdeyse tamamı (\%98'i) devletin girişimcilere yönelik teşvik ve desteklerinin yetersiz olduğunu ve artırılması gerektiğini belirtmişlerdir. Ayrıca mevcut destek ve teşviklerden gençlerin haberdar edilmesi sağlanmalıdır. Devlet girişimlerine yönelik teşvik ve desteklerin durumuna ait oranlar Tablo 5 'te belirtilmiştir.

Tablo 5. Devletin Girişimlerine Yönelik Teşvik ve Destekler

\begin{tabular}{lll}
\hline Açıklama & Frekans & Oran (\%) \\
\hline Yetersiz Bulan & 588 & 98 \\
\hline Yeterli Bulan & 12 & 2 \\
\hline Toplam & 600 & 100 \\
\hline
\end{tabular}

Genç girişimciliğinin en önemli sorunlarının başında sermaye yani para eksikliği gelmektedir. Sermaye temin edilebilecek kuruluşlar olan bankaların kredi miktarlarının az olması ve faizlerin yüksek olması araştırmaya katılanların \%80'i tarafından en büyük sorun olarak belirtilmiştir.

Tablo 6. Banka Kredileri ve Faizler

\begin{tabular}{lll}
\hline Açklama & Frekans & Oran (\%) \\
\hline Yetersiz Bulan & 480 & 80 \\
\hline Kararsız Olan & 120 & 20 \\
\hline Toplam & 600 & 100 \\
\hline
\end{tabular}

Yapılacak girişim için bilgi ve eğitim düzeyinin uygun olmaması genç girişimcilik engeli olarak belirlenmiştir. Gençlerin $\% 60^{\prime} 1$ aldıkları eğitim ile girişimci olamayacaklarını düşünmektedirler. Gençlerin sadece \%10'u ekonomik durum açısından kendi girişimlerini kurabilecek durumda olduklarını 
belirtmiştir. Bu nedenle gençlerin tamamı gençleri devletin desteklemesi ve gençlerin önünün açılması gereğini belirtmiştir.

Tablo 7. İlgi ve Eğitim Düzeyinin Uygun Olması

\begin{tabular}{lll}
\hline Açıklama & Frekans & Oran (\%) \\
\hline Yeterli Bulan & 60 & 10 \\
\hline Yeterli Bulmayan & 540 & 90 \\
\hline Toplam & 600 & 100 \\
\hline
\end{tabular}

Bir girişim fikrine sahip olan katılımcların oranı çok azdır (\%5- 30 kişi). Buna rağmen gençlerin $\% 90^{\prime} 1$ devlet kadrosunda veya düzenli maaşı olan bir işte çalışmak istediklerini belirtmişlerdir. Katılımcıların \%90'ının ailesinde girişimci bulunmamaktadır. Katılımcı gençlerin ailelerinin aylık gelir ortalaması 1750-2000 TL. aralığındadır. Ailesinde girişimci olanların \%10'unun ise babalarının girişimci olduğu ve küçük ölçekli işletme sahibi oldukları belirlenmiştir.

Genç nüfusun girişimcilik üzerindeki bilgisi ve düşünceleri ölçüldükten sonra yeni ve farklı bir girişimcilik türü olan sosyal girişimcilik bilgileri ölçülmeye çalışılmıştır. Bu bağlamda gençlerin bildikleri veya kamuoyundan duydukları sosyal girişimcilik örnekleri sorulmuştur. Gençlerin sosyal girişimcilikle ilgili bilgileri yok denecek kadar az olduğu ve çalışma kapsamında değinilebilecek anlamlı bir bulgunun olmadığı belirlenmiştir.

\section{Sonuç ve Öneriler}

Gençlik girişimciliği son yıllarda daha fazla ön plana çıkmıştır, ancak üniversite ortamında öğrenci girişimlerini veya "ekosistem" olarak da bilinen şirketlerin özelliklerini inceleyen az sayıda çalışma bulunmaktadır. Buna paralel olarak, üniversitelerin bu şirketlerin yerel kalkınmadaki rolünü araştıran daha fazla araştırmaya teşvik ettikleri söylenebilir. Gelişen dünyada üniversitelere sadece gençlerin eğitim gördükleri mekânlar olarak yaklaşılmasının ötesinde genç nüfusun uygulamada bilgi, beceri ve yaratıcılıklarını tümüyle değerlendirerek iş dünyasıyla etkileşime girmeleri ve yerel bağlamda yer almaları için artan bir talep sağlama görevi de düşmektedir.

Başarılı girişimciler iş fikirlerine değer katmak ve etkili çözümler geliştirmek amacı güderler. Günümüzde bilim ve teknolojideki ilerlemelerle henüz 
ortaya çıkmamış birçok girişimcilik fikri mevcut sorunlara çözüm olma firsatını beklemektedir. Bu yeni teknolojileri yaratan ve bunları farklı uygulama alanlarına yönlendiren genç girişimciler ise geleceğimizi şekillendirenlerdir.

Sosyal girişimcilik olarak bilinen yeni bir hareket ise küresel olarak 1980'lerde ortaya çıktı. Bu hareket, yenilikçi, sürdürülebilir ve değerlenebilir iş fikirleri ile toplumsal sorunları çözmeye yönelik yeni nesil girişimciler tarafından sahiplenildi. Bu hareketin büyümesi, oyuncuların ticari, sosyal ve kamu sektörlerinden davranışlarında, onları sektörler arası diyaloga ve ortak girişimlere yönlendiren bir dönüşümü tetiklemiştir. Sosyal girişimcilerden esinlenerek, şirketler geleneksel kurumsal sosyal sorumluluk politikaların,, toplumun yararına olan etki girişimlerine ve uygulamalarına giderek daha fazla katılarak değiştirmeye başlamışlardır. Sosyal girişimcilerin giderek artan görünürlüğü ve başarısı göz önüne alındığında, son on yılda, bu yenilikçi insiyatifleri ve organizasyonları finanse etmek için bir yatırım alanı yaratılmakta ve 2008 mali krizinden bu yana hız kazanmış olan finans sektöründe bir dönüşüm başlamıştır. Toplumsal girişimcilik, bu nedenle toplumda daha geniş bir alanı işgal eden ve gerçek anlamda etki odaklı bir ekonominin temellerini oluşturan bir harekettir. Her birimiz bu hareketin bir parçası olabiliriz. Bunun için toplum tarafından ihmal edilen, derinden anladığımız, soruna yeni bir çözüm geliştiren ve çözümü uygulamaya koyan, önemsediğimiz toplumsal bir soruna odaklanmamız gerekiyor.

Girişimcilik ile sosyal girişimcilik birbiriyle yakından ilişkili olarak üzerinde son zamanlarda sıkça durulan kavramlardır. Girişimcilik ister kar amacı gütsün ister gütmesin her bakımdan gençlerin gelişimine olumlu katkılar sağlamaktadır. Öncelik olarak kazanç sağlamaya yönelik girişimlere önem daha fazla verilse de zamanla sosyal girişimlere doğru eğilim artacak ve sosyal inovasyonlar da hak ettiği öneme kavuşacaktır.

Bu çalışma ile girişimcilik kavramı hakkında gençlerin bilgi düzeyi, genç girişimciliği kavramının önündeki engeller ve sosyal girişimciliği tanımlayan en önemli öğeler ve bilinen sosyal girişimcilik örneklerinin neler olduğuna dair oluşturulan araştırma sorularına cevap aranmıştır. Bayburt üniversitesinde öğrenim gören 600 öğrenciye uygulanan anket ile veriler toplanmıştır. Katılımcıların çok az bir kısmının ailelerinde girişimci olduğu belirlenmiştir. $\mathrm{Bu}$ nedenle girişimciliğe kendilerini uzak hissettiklerini vurgulamışlardır. Katılımcıların yarısı girişimcilik kavramı hakkında bilgi sahibi iken \%25’lik 
kesim girişimcilik kavramı hakkında bilgi sahibi olmadığını belirtmiştir. Katılımcılara genç girişimciliğinin önündeki en önemli engeller sorulduğunda sermaye eksikliği ve banka kredilerinden faydalanamadıklarını ilk sırada belirtmişlerdir. Gençlerin sadece \%10'u girişimcilik eğitimlerini yeterli bulmakta olup, özellikle girişimcilik eğitim programlarının artırılması ve mevcut eğitimlerin daha iyi gerçekleştirilmesi gereğini vurgulamışlardır. Üniversite öğrencileri devletin girişimcilere yönelik teşvik ve desteklerinin yetersiz olduğunu ve artırılması gerektiğini belirtmişlerdir. Ayrıca mevcut destek ve teşviklerden gençlerin haberdar edilmeleri gerektiğini belirtmişlerdir. Araştırma bulgularına bakıldığında yapılacak girişim için gençlerin bilgi ve eğitim düzeyinin uygun olmaması genç girişimcilik engeli olarak belirlenmiştir. Katılımcılara girişimcilik fikrine sahip olup olmadıkları sorulmuş fakat çok azı bir girişim fikrine sahip olduğunu belirtmiştir. Buna rağmen gençlerin $\% 90^{\prime} 1$ devlet kadrosunda veya düzenli maaşı olan bir işte çalışmak istediklerini belirtmişlerdir. Genç girişimciliğinin durumunu belirledikten sonra girişimciliğin toplumsal boyutunu ilgilendiren sosyal girişimcilik ile ilgili sorular sorulmuştur. Genç nüfusun girişimcilik üzerindeki bilgisi ve düşünceleri ölçüldükten sonra yeni ve farklı bir girişimcilik türü olan sosyal girişimcilik bilgileri ölçülmeye çalışılmıştır. Bu bağlamda gençlerin bildikleri veya kamuoyundan duydukları sosyal girişimcilik örnekleri sorulmuştur. Gençlerin sosyal girişimcilikle ilgili bilgileri yok denecek kadar az olduğu belirlenmiştir.

Sonuç olarak bu araştırma ile üniversite öğrencisi gençlerin girişimciliğe bakışı, girişimcilik hakkındaki fikirleri, girişimcilikten neden çekindikleri ve örnek aldıkları bir girişimci olup olmadığı belirlenmiştir. Genel olarak bulgulara bakıldığında katılımcı gençlerin girişimcilik algılarını engelleyen çok sayıda unsur olduğu görülmüştür. Girişimciliğin sosyal ve toplumsal boyutu olan sosyal girişimcilik hakkında hiçbir bilgi ve fikirlerinin olmaması ise diğer bir araştırma konusu olabileceği değerlendirilmektedir. Girişimcilik fikrine sahip olan öğrencilerin iş fikirleri de aile işletmelerine bağlı olarak oluştuğu görülmüştür. Gençleri en fazla girişimcilikten uzaklaştıran etmenlerin başında sermaye bulamama ve devlet yaptırımlarının fazla olduğu gelmektedir. Bu bağlamda bu gibi durumların önlenmesi için bu araştırma gibi çalışmalar dikkate alınarak bazı tedbirler alınması önerilebilir. Önerilerin başında gençlere girişim yapabilmeleri için imkân ve şartların düzenlenmesi gereği söylenebilir. Girişimcilik eğitimi okullarda ve üniversitelerde geliştikçe, ek araştırma ve değerlendirmelerin etkili programların geliştirilmesinde 
önemli bir rolü vardır. Umarız bu bulgular verimli bir diyalog ve daha fazla araştırma için bir başlangıç noktası olacaktır.

Çalışmanın sonuçlarının yanı sıra hem eğitimsel hem de toplumsal ve kurumsal bakış açısıyla daha fazla genç girişimciliğinin önemini vurgulayacak araştırma ve projelerin yapılması önerilebilir. Girişimcilik, istihdam yaratma ve işgücü piyasasına bağlılığın desteklenmesinde rol oynayabilir ve bunu son on yılda çeşitli programlarla gerçekleştirmiştir. Bununla birlikte, yılların deneyiminden, tüm gençlerin işgücü piyasasına entegre edilmesini sağlayacak hızlı bir çözüm olmadığı bilinmektedir. Bazı ülkeler diğerlerinden daha iyi bir iş çıkarsa da, tüm ülkeler sahip oldukları genç nüfusa yardım etme konusunda baskı ve zorluklarla karşı karşıyadır. Ekonomik büyüme ve makroekonomik düzeyde iş yaratma, kendi içinde yeterli olmamakla birlikte bu sorunların çözümünün önemli bir parçasını oluşturmaktadır.

Genç nüfus farklı gruplardan oluşmakta ve bu gruplar arasında girişimcilik potansiyelleri ve karşılaştıkları engeller bakımından bazı önemli farklılıklar vardır. Özellikle etnik azınlıklar, yoksul bölgelerde yaşayanlar, düşük gelirli ailelerden gelenler ve düşük eğitim seviyesine sahip olan gençlerin karşılaştıkları işgücü piyasası zorluklarıyla başa çıkması daha zor olmaktadır. Bununla beraber genellikle en büyük engellerle karşı karşıya olduğu tespit edilen grup, istihdam, eğitim veya öğretime sahip olmayan gruptur (OECD, 2018). Bu grubun tehlike arz etmesinden dolayı politika yapıcılar için kilit öneme sahip hedef gruptur. Etnik farklılıklara sahip gençliğin girişimcilik için daha fazla engelle karşı karşıya olduğunu düşünebiliriz, ancak bu durumun gerçekten doğru olup olmadı̆̆ı konusunda araştırma sonuçları kesin değildir (Osterbeek, Van Praag ve Ljsselstein, 2010).

Tüm gruplar için tamamen aynı olan bazı engeller ve politika önlemleri olsa da, farklı gençlik grupları için desteğin ölçeklerini ve niteliklerini değiştirmeye ihtiyaç duyulabilir. Özellikle, dezavantajlı gençler, zor bir ortamda yaşayanlar veya finansal, insan ve sosyal ağ sermayesinde önemli boşluklar bulunan gençler arasında bir ayrım yapılabilir. Ayrıca uygun politika müdahalesiyle başarılı öğrencilerin girişimcilik katılımını arttırma fırsatı da sunulabilir.

Öncelikle girişimciliğin geliştirilmesi için gençlere girişimci bir zihniyet kazandırılması gereklidir. Yaşları 18 ile 30 arasında olan gençler arasında girişimci zihniyetin geliştirilmesi ve teşvik edilmesi ve iş bulma veya küçük işletmelerin yaratılması için gerekli becerilerin kazandırılması, başarılı gençlik 
girişimcileri geliştirmek için uzun bir yol kat edilmesi gerekmektedir. Gençlerin yeni şeyler denemek için teşvik edilmesi gerekmektedir. Çünkü yaş büyüdükçe risk almaktan giderek daha da uzaklaşılmak istenmekte ve güven ve cesaret kalmayacaktır. Bu nedenle, toplumu gençliğin girişimcilik ile hem paranın hem de başarının kazanılabileceği gerçeğine göre harekete geçirmek ve hassaslaştırmak gerekir.

Girişimcilik eğitimlerinin önemli olduğu düşünülse de bunun geçerliliği hakkında yani girişimlerin başlamasına yol açıı̆ııı gösteren kanıtlar yetersizdir. Belçika, Danimarka, Almanya ve ABD'de yapılan birçok çalışmanın ortak sonucuna göre, öğrencilerin girişimciliğe ilgisi okullarında girişimcilik konusu onlara anlatıldıktan sonra artış göstermektedir (ILO, 2006; Lepoutre ve diğerleri, 2010).

Sosyal ağ ilişkileri ile bilgi ve beceri eksikliği, tesis, ekipman ve finansman gibi girişimlere başlangıç aşamasında karşılaştıkları eksiklikleri kapsayan tüm engellerin üstesinden gelmede gençlere yardımcı olacak destekleyici bir altyapı sağlayarak ülkelerin genç girişimcileri desteklemesi gerekir. Bunun için yapılması gereken önlemler arasında teknoloji merkezleri, biyoteknoloji sahaları, serbest bölgeler, sanayi siteleri, girişimci ağları ve işletme kuluçka merkezleri bulunmaktadır. Gençlik iş ağları ve dernekleri genç girişimciler için önemlidir, çünkü gençlerin beklenti ve hedeflerini devlete ve sanayiye göstermek için karşılıklı öğrenme fırsatları, iş bağlantıları ve ortak fırsatlar sağlarlar (Chigunta, 2002).

Girişimlere başlamak isteyen gençlerin, bilgi ve beceri boşluklarını doldurmaya yardımcı olmak için bilgi, tavsiye, koçluk ve mentorluk gibi destek sağlayanlara ihtiyaçları vardır. Başlangıç sermayesi bulamama ve finansman sağlama zorluğu, girişimciler için iş kurma girişimlerinin önündeki ciddi bir engel olarak tanımlanmaktadır.

Güven temelli insan ilişkileri geliştirme, hedef belirleme, yaratıc problem çözme ve eleştirel düşünme gibi yaşam becerileri, genç girişimcilerin hedeflerine ulaşmasında esastır. Bu beceri eksikliğini, yoğun bir eğitim ile yürütülen ve daha sonraki aşamalarda da sürdürülen bir sosyal içerme süreciyle tamamlamak için yaşam becerileri ve girişimcilik konularında genç girişimciler için eğitimler sağlanmalıdır. Kurulan ve gelişen girişimcilere beceri eğitimi, iş geliştirme yardımı ve sorun giderme konularında bilgi sağlama için imkânlar sunulmalıdır. Bununla birlikte gençlerin yaratıcılı̆̆ını teşvik etmek ve gençlik gruplarını yenilikçi iş fikirleriyle aydınlatmak için yarışmalar ve 
toplantılar düzenlemeye ihtiyaç vardır. Tüm bu gereksinimlerin yanında ürünlerin fizibilitesini değerlendirmek, pilot çalışmalar yürütmek ve işletme sahiplerinin ihtiyaçlarını karşılamak için bilgi teknolojileri ve sistemleri kullanılarak çözümler geliştirmek için araştırma yapmak katkı sağlayacaktır. 


\section{EXTENDED ABSTRACT}

\section{Youth Entrepreneurship And Social Entrepreneurship: A Research On University Student \\ Hale Alan \\ Akdeniz University}

This study aims to identify the status of youth entrepreneurship and factors hindering youth entrepreneurship and to measure the perception and knowledge levels of young people about the concept of social entrepreneurship that has been on the agenda very often in recent years. For this purpose, it is aimed to contribute to the literature based on the research questions determined. The research was conducted on youth population between the ages of 18-35 who were studying at a State University and the data was collected from 600 students selected as samples using a survey compiled from both domestic and foreign literature.

In this study, the concept of youth entrepreneurship, which has been emphasized as a type of entrepreneur, has been the focus of the studies, which have received great interest in recent years. Particularly in developing countries with a high number of young people, it can be said that directing youth to entrepreneurship, preventing unemployment and increasing employment are among the most emphasized issues. Barriers to youth entrepreneurship are similar to other entrepreneurship barriers. These obstacles frighten young entrepreneurs and prevent them from becoming entrepreneurs in the future. At the same time, it is seen as a restrictive threat for existing entrepreneurs (Jain and Ali, 2013: 91). Eliminating or reducing these barriers is important as it will encourage new entrepreneurs and facilitate existing entrepreneurs. Therefore, first of all, these barriers come first to determine what is happening, and then it will be useful to investigate their causes and examine their relationship with other variables. Another concept emphasized in this study is the concept of social entrepreneurship and it can be defined as the solutionoriented gathering of the individuals and the layers of society for the problems concerning society. Social initiatives come to the agenda very often in the world and for social needs of societies, until the problem is solved, they 
appear as the structures established by the people who establish and implement sustainable systems as a life objective. The main purpose of social entrepreneurship is to produce social value.

The research questions are as follows:

- What is the level of knowledge of young people about the concept of entrepreneurship?

- What are the barriers to youth entrepreneurship?

- What are the most important factors defining social entrepreneurship and examples of known social entrepreneurship?

The article is based on quantitative analyses. The online questionnaire and hardcopy questionnaire form were used as data collection tools. While preparing the questionnaire, a necessary literature review was conducted and questions related to the concept of youth entrepreneurship, entrepreneurship barriers and social entrepreneurship in our country were included. The first seven questions used in the study and included in the first part of the questionnaire prepared exclusively for this study contain descriptive and demographic information about the students who answered the questionnaire. These questions are related to the age, sex, and department, social and economic status of the participants. The second part of the questionnaire covers twenty-seven questions for the research and the search for answers to the research questions. In the last part of the survey, there are five questions to determine the perception of social entrepreneurship. In the last section, the answers of the students to the questionnaire consisting of open-ended questions were evaluated using systematic analysis and descriptive analysis methods. Using a random sampling method and 600 students participated in the study.

In this study, the level of knowledge of young people about the concept of entrepreneurship, the obstacles to the concept of young entrepreneurship and the most important elements defining social entrepreneurship and the examples of known social entrepreneurship were searched. Data were collected with a questionnaire applied to 600 students studying at Bayburt University. Very few of the participants were found to be entrepreneurs in their families. Therefore, they emphasized that they felt distant from entrepreneurship. While half of the participants had information about the concept of entrepreneurship, 25\% stated that they did not know about the concept of entrepreneurship. When the participants were asked about the most important barrier to youth entrepreneurship, they stated that they did not benefit from the lack 
of capital and bank loans. Only $10 \%$ of young people find entrepreneurship training sufficient and emphasized the need to increase entrepreneurship training programs and better the existing training. University students indicated that the government's incentives and supports for entrepreneurs were insufficient and needed to be increased. They also stated that young people should be informed of the current support and incentives. According to the findings of the study, the lack of knowledge and education level of young people was found to be a young entrepreneurship barrier. Participants were asked if they had the idea of entrepreneurship, but few indicated that they had an idea of entrepreneurship. However, $90 \%$ of the youth stated that they wanted to work in the state staff or a regular salary. After determining the status of young entrepreneurship, questions were asked about the social entrepreneurship that concerns the social dimension of entrepreneurship. After the knowledge and thoughts of the young population on entrepreneurship were measured, it was tried to measure social entrepreneurship that is a new and different type of entrepreneurship. In this context, examples of social entrepreneurship that young people know or heard from the public were asked. It is determined that young people have very little knowledge about social entrepreneurship.

As results, it was determined that university students' perspective on entrepreneurship, their ideas about entrepreneurship, why they are afraid of entrepreneurship and whether they are an entrepreneur or not. In general, when the findings are examined, it is seen that many factors prevent the participants' perception of entrepreneurship. It is considered that the lack of knowledge and ideas about social entrepreneurship which is the social dimension of entrepreneurship may be another research subject. It is seen that the business ideas of the students who have the idea of entrepreneurship are formed depending on the family businesses. Lack of capital and state sanctions are the most important factors that keep young people away from entrepreneurship. In this context, it may be suggested to take some measures to prevent such situations by taking into consideration studies such as this research. At the beginning of the proposals, it can be said that the opportunities and conditions should be arranged for young people to make initiatives. 


\section{Kaynakça / References}

Acs, Z. J., Autio, E., Szerb, L. (2014). National systems of entrepreneurship: Measurement issues and policy implications. Research Policy, 43(3), 476-494.

Akyurt, N. (2018). Üniversite öğrencilerinin girişimcilik eğilimlerinin belirlenmesi: sağlık örneği. Medical Sciences, 13 (2) , 43-57.

Arshed, N., Carter, S., Mason, C. (2014). The ineffectiveness of entrepreneurship policy: Is policy formulation to blame? Small Business Economics, 43(3), 639-659.

Astebro, T., Bazzazian, N., Ve Braguinsky, S. (2012). Startups by recent university graduates and their faculty: Implications for university entrepreneurship policy. Research Policy, 41(4), 663-677.

Bergmann, H., Hundt, C., ve Sternberg, R. (2016). What makes student entrepreneurs? On the relevance (and irrelevance) of the university and the regional context for student start-ups. Small Business Economics, 47(1), 53-76.

Bosma, N. S., ve Levie, J. (2010). Global Entrepreneurship Monitor 2009: Executive Report. Babson Park, MA: Babson College, Universidad del Desarollo, Ha'sko'linn Reykjavi'k University and Global Entrepreneurship Research Association.

Bruton, G. D., Ketchen, D. J., ve Ireland, R. D. (2013). Entrepreneurship as a solution to poverty. Journal of Business Venturing, 28(6), 683-689.

Buchert, L. (2014). Learning needs and life skills for youth: An introduction. International Review of Education, 60(2), 163-176.

Chigunta, F. (2002). Youth entrepreneurship: Meet $\rightarrow i n g$ the key policy challenges. Oxford, UK: Oxford University.

Choo, S. ve Wong, M. (2006). Entrepreneurial Intention: Triggers and Barriers to New Venture Creations in Singapore. Singapore Management Review, 28(2), 47-64.

Dash, M., ve Kaur, K. (2012). Youth entrepreneurship as a way of boosting Indian economic competitiveness: A study of Orissa. International Review of Management and Marketing, 2(1),10-21.

Dees, J. G. (1998a). Enterprising nonprofits. Harvard Business Review, 76, 55-67.

Finnerty, J. F. ve Krzystofik, A. T. (1985). Barriers to Small Business Formation. Journal of Small Business Management, 23(3), 50-58.

Gregg, P. (2001). The impact of youth unemployment on adult unemployment in the NCDS. The Economic Journal, 111(475), F623-F653.

Hancıoğlu, Y., ve Tekin, E. (2018). Genç girişimci adaylarının girişimcilik eğilimlerinin değerlendirilmesi: Uygulamalı girişimcilik kampüsü üzerine bir araştırma. Cankır Karatekin University Journal of the Faculty of Economics and Administrative Sciences, 8(1), 213-246. 
Hatala, J. P. (2005). Identifying barriers to self employment: The development and validation of the barriers to entrepreneurship success tool. Performance Improvement Quarterly, 18(4), 50-70.

Hayes, David Ve Richmond, William. (2017). Using an online assessment to examine entrepreneurship student traits and to measure and improve the impact of entrepreneurship education. Journal of Entrepreneurship Education, 20 (1), 88107.

İpçioğlu, I. ve Taşer, A. (2009). İşletme bölümlerinde verilen eğitimin girişimci adayı öğrenciler üzerindeki etkileri. Süleyman Demirel Üniversitesi Sosyal Bilimler Enstitüsü Dergisi, 2(10), 13-25.

Jain, R. ve Ali, S. W. (2013). Self-efficacy beliefs, marketing orientation and attitude orientation of Indian entrepreneurs. Journal of Entrepreneurship, 22(1), 71-95.

Kayalar, M. ve Ömürbek, N. (2007). Girişimci adaylarının risk almaya yatkınlık özelliğinin cinsiyet bağlammda incelenmesi, İktisadi ve İdari Bilimler Dergisi, 21(1), 185-200.

Kutanıs, Ö. R. (2006). Girişimci kadınlar. İstanbul: :Değişim Yayınları

Lepoutre, J., Van Den Berghe, W., Tilleuil O., ve Crijns, H. (2010). A new approach to testing the effects of entrepreneurship education among secondary school pupils. Vlerick Leuven Gent Working Paper Series 2010/01.

Lepoutre, J., Justo, Terjesen, S. ve Bosma, N, (2013). Designing a global standardized methodology for measuring social entrepreneurship activity: the Global Entrepreneurship Monitor social entrepreneurship study, Small Business Economics, 40, 693-714

Mair, J., ve Marti, I. (2006). Social entrepreneurship research: A source of explanation, prediction, and delight. Journal of World Business, 41(1), 36-44.

Med, T., ve Lukyamuzi, A. (2019). Addressing pedagogical usability and mobility barriers in e-learning systems: A case of youth entrepreneurship skill development, plan international Uganda. International Journal of Sustainable Development Research. 5(3), 56-70

Moberg, K.. (2012). The impact of entrepreneurship education and project-based education on students' personal development and entrepreneurial intentions at the lower levels of the educational system: Too much of two good things?. SSRN Electronic Journal. 10.2139/ssrn.2147622.

Mosey, S., Noke, H. ve Binks, M. (2012). The influence of human and social capital upon the entrepreneurial intentions and destinations of academics, Technology Analysis \& Strategic Management, 24(9), 893-910 
Nasser, M. E., Du Preez, J., ve Herrmann, K. (2003). Flight of the young flamingoes: alternative futures for young entrepreneurs in South Africa. Futures, 35(4), 393-401.

OECD. (2018). Off to a good start, jobs for youth. Paris, France: OECD.

Osterbeek, H., Van Praag, M., ve Ijsselstein, A. (2010). The impact of entrepreneurship education on entrepreneurship skills and motivation. European Economic Review, 54(3), 442-454.

Örücü, E., Kılıç, R. ve Yılmaz, Ö. (2007). Üniversite öğrencilerinin girişimcilik eğilimlerinde ailesel faktörlerin etkisi üzerine bir uygulama. Girişimcilikve Kalkınma Dergisi, 2(2), 27-47.

Pihie, Z. A. L. ve Akmaliah, Z. (2009). Entrepreneurship as a career choice: An analysis of entrepreneurial self-efficacy and intention of university students. European Journal of Social Sciences, 9(2), 338-349.

Potter, J. (Ed.). (2008). Entrepreneurship and higher education. Paris, France: OECD.

Salık, N. ve Kaygın, E. (2016). Demografik değişkenler açısından üniversite öğrencilerinin girişimcilik eğilimlerinin belirlenmesi: Kafkas Üniversitesi öÖrneği. KSÜ Sosyal Bilimler Dergisi, 13(1), 145-162.

Seelos, C., ve Mair, J. (2005). Social entrepreneurship: Creating new business models to serve the poor. Business Horizons, 48(3), 241-246

Short, J. C., Moss, T. W., ve Lumpkin, G. T. (2009). Research in social entrepreneurship: Past contributions and future opportunities. Strategic Entrepreneurship Journal, 3(2), 161-194.

Smith, B. R., ve Stevens, C. E. (2010). Different types of social entrepreneurship: The role of geography andembeddedness on the measurement and scaling of social value. Entrepreneurship \& Regional Development, 22(6), 575-598

Solmaz, S. A., Aksoy, Ö., Şengül, S. ve Sarışık, M. (2014). Üniversite öğrencilerinin girişimci kişilik özelliklerinin belirlenmesi: Turizm lisans ve ön lisans öğrencileri üzerine bir alan araştırması. KMÜ Sosyal ve Ekonomik Araştırmalar Dergisi, 16(26), 41-55.

Trexler, J. (2008). Social entrepreneurship as an algorithm: Is social enterprise sustainable? Emergence: Complexity and Organization, 3(10), 65-85.

Thompson, E.R. (2009). Individual entrepreneurial intent: Construct clarification and development of an internationally raliable metric. Entrepreneurship Theory and Practice, 33(3), 669-694.

Yetim, N., (2014). Sosyal Sermaye Olarak Kadın Girişimciler: Mersin Örneği, Ege Üniversitesi Ege Akademik Bakış, 
Wright, M., Siegel, D. S., ve Mustar, P. (2017). An emerging ecosystem for student start-ups. The Journal of Technology Transfer, 42(4), 909-922

Yılmaz, B.S. ve Günel, Ö.D. (2011). Üniversite eğitimi ve girişimcilik: Bireyleri girişimciliğe yönlendiren etkenler üzerine bir araştırma. Akademik Bakış Dergisi, 26, $1-20$.

Yüksel, H., Cevher, E. ve Yüksel, M. (2015). Öğrencilerin girişimci kişilik özellikleri ile girişimcilik eğilimleri üzerine bir araştırma. Çankır Karatekin Üniversitesi İktisadi ve İdari Bilimler Fakültesi Dergisi, 5(1), 143-156.

Zahra, S. A., Gedajlovic, E., Neubaum, D. O., ve Shulman, J. M. (2009). A typology of social entrepreneurs: Motives, search processes and ethical challenges. Journal of Business Venturing, 24(5), 519-532.

\section{Kaynakça Bilgisi / Citation Information}

Alan, H. (2020). Genç girişimciliği ve sosyal girişimcilik: Üniversite öğrencileri üzerinde bir araştırma. OPUS-Uluslararası Toplum Araştırmalarn Dergisi, 16(28), 997-1027. DOI: 10.26466/opus.679627 